\title{
New venture dissolution and the comobility of new venture teams
}

\author{
Nazanin Eftekhari $\cdot$ Bram Timmermans
}

Accepted: 4 July 2021 / Published online: 2 October 2021

(C) The Author(s) 2021, corrected publication 2022

\begin{abstract}
While the dissolution of new ventures is a common phenomenon in the organizational landscape, it seldom means the end of the road for those involved in the new venture. Nevertheless, most research treats this dissolution with a sense of finality. Using the Danish Integrated Database for Labor Market Research (IDA), we explore the persistence of cofounders and early employees to continue their work relationships after the dissolution of the new venture. We investigate where these team members continue their career and whether they pursue entrepreneurship together in another new venture. Overall, over $18.3 \%$ move jointly, and comobility is more prevalent among new venture team members who worked jointly prior to founding the new venture and among those new venture teams demonstrating high levels of homogeneity. Moreover, comovers tend toward small firms, and comobility occurs largely in similar industry. A large share of comovers move to new ventures, which is indicative of serial or habitual new venture teams. This also raises further question on team-level dimension of learning from failure.
\end{abstract}

N. Eftekhari · B. Timmermans

Aalborg University Business School, Fibigerstræde 11, 9220 Aalborg Øst, Denmark

B. Timmermans $(\bowtie)$

NHH Norwegian School of Economics, Helleveien 30, 5045 Bergen, Norway

e-mail: Bram.Timmermans@nhh.no
Plain English Summary There is lots of empirical research that investigates the emergence and growth of team-based new ventures. But what happens with these new venture teams when the business they established closes? Do these teams outlive the startup itself? In this study, we investigate this topic in detail by following the career trajectories of new venture team (NVT) members. Based on a sample of 2400 team-based Danish startups, we find that $18 \%$ of NVT members continue their collaboration. The results demonstrate that similarity between NVT members, the extent that they are engaged in knowledge intensive work, and prior joint work experience are drivers of such comobility. Also, we find that NVT comobility often means re-entering into entrepreneurship. The fact that such comobility is common and that many re-enter into entrepreneurship means that our study has implications for both research and practice. More specifically on how learning from failure takes place in the setting of NVT teams.

Keywords Failure $\cdot$ Dissolution $\cdot$ Comobility $\cdot$ New Venture Teams

JEL Classifications $\quad \mathrm{L} 26 \cdot \mathrm{M} 13 \cdot \mathrm{J} 60 \cdot \mathrm{J} 62 \cdot \mathrm{J} 65$

Each year, many entrepreneurs are confronted with the often-bitter reality of having to close down a business they only recently established. Given that new ventures face challenges associated with liabilities of 
newness and smallness (Bruderl \& Schussler, 1990; Stinchcombe, 1965), a large share of new ventures close down only a few years after they got established. For instance, 5-year survival rates for the USA, UK, and Denmark are respectively 58\% (US Bureau of Labor Statistics, 2021), 42\% (Eurostat, 2020), and 38\% (Eurostat, 2020). This makes new venture dissolution one of the most prominent events in any country's organizational landscape. In investigating the implications of the closure of a new venture, research has mainly focused on the individual entrepreneur (see Ucbasaran et al., 2013). Jenkins and McKelvie (2017) noted that this research treats such events with a sense of finality and expressed the need to understand what happens to entrepreneurs and their resources in the aftermath of a dissolution. In doing so, they demonstrated that most entrepreneurs remain active in the labor market.

While these studies have investigated the implications for individual entrepreneurs, the consequences for teams are less understood. However, since a sizeable share of new ventures are founded and run by teams (Coad \& Timmermans, 2014; Klotz et al., 2014), understanding what happens with teams following the closure of their business provides us with valuable insights into the mechanism, dynamics, and implications related to entrepreneurship and failure. In this paper, we investigate the post-dissolution mobility of new venture team (NVT) members in more detail. Focusing on the NVT not only offers perspective on what happens to the team following the dissolution but also allows us to capture the transfer of one of the most intangible assets of a former venture: the shared experience and team-based human capital of NVT members. In case a new venture closes, shared human capital might evaporate whenever the NVT members go their separate ways. Just as an NVT might leverage the previous shared experience of team members (Zheng, 2012), NVT members can, after the new venture has dissolved, continue working as colleagues, either to capitalize on their shared human capital or because their shared experience and awareness of each other's knowledge, skills, and competences allow for effective collaboration and communication. While post-dissolution mobility can be associated with relevant knowledge transfers (Hoetker \& Agarwal, 2007), the fact that NVT members comove might be yet another indication that even when the new venture closes this does not mean that all aspects of the new venture failed (Coad, 2014).

To investigate the phenomenon of NVT comobility, we conduct our analysis on a large sample of Danish new ventures. The Danish entrepreneurial landscape has proven to be a valuable empirical setting to study issues surrounding wages (Burton et al., 2018), career background of entrepreneurs (Dahl \& Reichstein, 2007), and team composition of new ventures (Coad \& Timmermans, 2014; Kaiser \& Müller, 2015) that shows lots of similarities to other countries in northern Europe (Dahl \& Sorenson, 2012). In addition, the Danish context provides us with access to the rich data available from the Danish register (IDA) which allows us to identify all newly registered firms with two or more individuals. We follow these new ventures and their teams and select those that dissolved within 5 years of founding. We follow the career trajectory of the NVT members following the dissolution and identify where they move to if they remain together after the dissolution. Because we are interested in understanding the determinants of comobility, we focus on the relationship that exists between NVT members and, more specifically, on the relationship between individual pairs or dyads. In previous studies on entrepreneurship and teams, the focus on dyads has proven to be methodological meaningly (Coad \& Timmermans, 2014; Harper, 2008), while it also has been applied in studying comobility of workers (Marx \& Timmermans, 2017).

In examining the career trajectory, we identify that $7.9 \%$ of the dyads (representing $18.3 \%$ of all individuals) re-appear in organizations with former NVT members. Although comobility might occur due to perceived benefits of staying together, there are some hints that this comobility also occurs due to necessity, for example, as it might be challenging to transition into ordinary form of employment (Mahieu et al., 2019). In the analysis, we investigate in detail the determinants of NVT members' comobility. Main drivers are similarity between NVT members, the extent that they are engaged in knowledge intensive work, and prior joint work experience, which indicates that there are workers who follow each other in their careers. Finally, we find that NVT comobility often means re-entering into entrepreneurship, which provides some interesting question for future research, for example, how this will affect performance and 
how learning from failure takes place in the setting of NVT teams.

The structure of this paper is as follows. In the next section, we discuss the overall theoretical framework and hypotheses. Subsequently, we describe the data, sample, and models, and then the results. The last section provides an overall discussion of our results and recommendations for future research.

\section{Theory and hypotheses}

\subsection{New venture dissolution and NVT comobility}

When entrepreneurs close their ventures, often due to bankruptcy or otherwise poor performance, it is generally associated with a lot of stigma. This, in turn, affects the entrepreneur psychologically (Cope, 2011; Shepherd, 2003; Singh et al., 2007) and has repercussions for their future career (Eklund et al., 2020; Simmons et al., 2014). Understandably, these issues have received much attention in the research on entrepreneurship and failure. However, bankruptcies and so-called failures also provide opportunities. After all, the vast majority will continue their career, either as an employee for an established firm or by starting another venture, hopefully having learned from their previous attempt at entrepreneurship (Nielsen \& Sarasvathy, 2016).

This demonstrates that the closure of a new venture cannot unequivocally be regarded as a failure (Coad, 2014; Head, 2003; Ucbasaran et al., 2013; Wennberg \& DeTienne, 2014). Entrepreneurs that experience bankruptcies corroborate this claim and hold the view that despite bankruptcy, the entrepreneurship process has provided them with an incredible learning opportunity (Eftekhari, 2020). Thus, as Jenkins and McKelvie (2017) argued, instead of marking this event as the closure of a business, the forfeiture of an entrepreneurial opportunity, or even the end of a career, it should be considered part of a dynamic process where the opportunity, through employee mobility, is explored in another organizational setting.

Since most will keep pursuing their career, the dislocation following the closure offers possibilities for knowledge transfer. There is a well-established literature that demonstrates how employee mobility leads to the transfer of knowledge and capabilities, both within and between firms (Almeida \& Kogut, 1999; Song et al., 2003; Campbell et al., 2012). Within this literature, Hoetker and Agarwal (2007) have demonstrated that such knowledge transfers also occur following the closure of the business. Employee mobility helped to retain knowledge and capabilities, which offered value in other organizational settings. Subsequently, the knowledge and capabilities have outlasted the existence of the businesses from where they originated. Thus, as stated by Ingram (2002): "The experience of a failed organization might be particularly likely to diffuse through employee mobility as participant in the failure go to new jobs" (p. 657).

In understanding employee mobility and knowledge transfer, research tends to focus on the individual, also when linking them to the dissolution of the (new) venture. However, a large share of new ventures are founded and run by teams (Klotz et al., 2014), which opens up a more collective perspective in how such knowledge transfers can take place. After all, the experience they have accumulated as a team might be of value long after the business has closed. There might thus be a motive for NVT members and possible future employers to preserve this knowledge through comobility.

From the moment (new venture) team members collaborate, they build a shared history and develop shared experiences and routines (Pisano, 1994). Through these shared experiences, they obtain information on the knowledge, skills, and demographic characteristics of their fellow teammates (Balkundi \& Harrison, 2006; Gruenfeld et al., 1996; Zheng et al., 2016). This allows teams to plan more sensibly, assign tasks to those who are best at performing them, and coordinate more effectively as team members can anticipate each other's behavior - a transactive memory system (Lewis, 2004; Moreland \& Myaskovsky, 2000). In addition, this interaction results in building team-specific human capital (Huckman et al., 2009). Besides an immediate human capital effect, such collaboration strengthens mutual trust among team members, which might lead to additional performance gains (McEvily et al., 2003). To benefit from these shared experiences, comobility needs to occur.

Research has demonstrated that both organizations and individuals can benefit from comobility. Campbell et al. (2014) argue that relying on shared experience allows them to more quickly achieve their 
productive potential as it mitigates negative performance shocks that are common after workers change their workplace. Groysberg et al. (2008) argue that the expected contribution of new hires declines if they are separated from their team members. Marx and Timmermans (2017) demonstrated that workers can share in the rents of the expected higher performance effects associated with comobility. Also, comobility may contribute to a faster emotional and psychological recovery from the failure experience (Dokko et al., 2009).

Admittedly, comobility among NVT members might be driven by motives that are unrelated to the benefits of shared experiences per se. For example, working in teams might make it harder to assess their individual contributions (Alchian \& Demsetz, 1972). This might constrain mobility for the individual contributor and force them to seek new employment opportunities collectively, which might compel them to re-enter into entrepreneurship. Alternatively, comobility might be the result of referrals rather than of the shared experience. Cingano and Rosolia (2012) have demonstrated that former colleagues are an important source for securing a new job following the dissolution of the workplace.

\subsection{Comobility and Re-entry into Entrepreneurship}

Comobility can also be a vehicle for NVTs to give new life to existing business ideas. Transitioning into or, in this case, re-entering into entrepreneurship is a common choice for those who are displaced due to the closure of the new venture. Often, such re-entry appears relatively seamless (Jenkins \& McKelvie, 2017). Such seamless transition might be more pronounced when NVT members decide to join forces in a new venture as a serial entrepreneurial team.

Research shows that both success and failure facilitate learning that is beneficial for future venture creations (Marvel, 2013). Team members might have developed tacit knowledge of entrepreneurship, which provides them with more entrepreneurial experience to recognize and evaluate potential opportunities (Baron \& Ensley, 2006; Ucbasaran et al., 2009). There are thus motives for NVT members to make another attempt at entrepreneurship following the dissolution. Such attempts are not uncommon, as many entrepreneurs might see "failure" as part of the entire entrepreneurial process (Sarasvathy et al., 2013).
The presence of joint experience provides collective knowledge that guides the subsequent entrepreneurial process and reduces errors (Nielsen \& Sarasvathy, 2016; Witt, 2000). It also improves the ability to mitigate adverse performance effects (Campbell et al., 2014). This allows NVT members to undertake aspects of new venture activities more effectively (Delmar \& Shane, 2006) and helps them to understand the role they might have to play in the new venture. Finally, staying together may provide the restart venture with greater legitimacy and access to financial, social, and human resources (Kor \& Mahoney, 2000). Overall, it thus helps tackle the challenges associated with the new venture's liability of newness (Stinchcombe, 1965).

However, comobility into entrepreneurship is not always voluntary. Often, "failed" entrepreneurs are punished by the labor market, which means that the decision to re-enter might be driven by necessity (Mahieu et al., 2019). Comobility into entrepreneurship might be an outcome of NVT members that abandon their individual or possibly collective job search and decide to re-enter into entrepreneurship instead. Rocha et al. (2018) demonstrated that people who were pushed into entrepreneurship following a spell of unemployment were more inclined to rely on former co-workers to join them in the new venture.

\subsection{Determinants of NVT Comobility}

Based on the above arguments, we expect that (i) comobility is an often-observed phenomenon among NVT members and (ii) NVT members have an incentive to re-enter into entrepreneurship. A relevant follow-up question, however, would be what the determinants of comobility are. This research question will be addressed by formulating a set of hypotheses that guide our empirical analysis. As drivers, we emphasize the role of homophily, human capital characteristics, prior joint work experience, and new venture performance.

\subsubsection{Homophily and NVT comobility}

As a first hypothesis, we focus on the demographic characteristics of NVT members, which include variables such as gender, age, and national background. A well-established principle of social organization is the tendency of individuals to associate themselves with 
others with whom they share similar attributes, i.e., social categorization theory (Lazarsfeld \& Merton, 1954; McPherson et al., 2001). This pattern of homophily is observed in a broad-range workplace setting (McPherson \& Smith-Lovin, 1987; Kleinbaum et al., 2013).

The argument as to why we expect homophily as a driver is that such ties build on a common language, similar knowledge base, and shared set of values and norms. All these contribute to the ease of interaction and a high predictability of behavior (Kossinets \& Watts, 2009). This leads to less (personal) conflict, which positively contributes to the effective use of resources and time (Balkundi \& Harrison, 2006; Dahlander \& McFarland, 2013). Furthermore, homophily is associated with more solidarity (Kossinets \& Watts, 2009), which helps individuals cope better during times of hardship (Kim \& Aldrich, 2002).

The principle of homophily is also pronounced in NVT. Ruef et al. (2003), Parker (2009), and Gompers et al. (2017) demonstrate that founders tend to be similar in their observed characteristics and beliefs. Early recruitment decisions strengthen similarity as founders tend to hire workers that resemble themselves (Molina \& Kacperczyk, 2017; Bublitz et al., 2018). Finally, homophilic NVTs are associated with team stability, as they experience less team member turnover (Kim \& Aldrich, 2002). The latter provides additional support to the claim that similarity in ties makes the team less likely to dissolve (Lazarsfeld \& Merton, 1954; McPherson et al., 2001). We would thus expect that homophilic ties within NVTs are persistent and survive the dissolution of the new venture. This culminates in the following hypothesis.

H1: Comobility is more likely to occur among NVT members that are homogeneous in their demographic characteristics.

\subsubsection{Human capital characteristics and comobility of NVT}

In this section, we turn our attention to human capital, more specifically how the interdependence, codependence, or joint specialization among NVT members might increase the likelihood of comobility.

In Sect. 2.1, we already pointed to the fact that interaction in NVTs, which some have described as more intense compared to that among work teams in established firms (Zheng et al., 2016), leads to the development of a transactive memory system, formation of team-specific human capital, and establishment of mutual trust among NVT members. These are all motives for former colleagues to resume their coworker relationship in another form of employment (Chillemi \& Gui, 1997; Marx \& Timmermans, 2017; Zheng, 2012; Zheng et al., 2016), especially as such shared experience can be readily applied in another organizational setting (Reagans et al., 2004).

However, whether such integration takes place depends on the level of cognitive interdependence of work. For example, previous studies observe that such interdependence is more pronounced among knowledge workers (Lewis, 2004). Consequently, we formulate the following hypothesis.

H2a: NVT members working in knowledge-intensive occupations and industries are more likely to move jointly after a new venture dissolves than a team of people in other occupations.

In addition, workers with a technical background are more inclined to work on joint projects due to the cognitive interdependence of technical work. They rely on common tools and mental models to discuss and may find joint projects to work on. Furthermore, because of the complexity of technical work (Janz et al., 1997), individuals need to work with others, both to add more knowledge and to share and test ideas.

The above is corroborated by Lewis (2004), who demonstrates that such effects are stronger in technical team members since mechanisms of transactive memory systems facilitate the encoding, storing, and retrieving of knowledge among team members, which are important elements in technical professions. Admittedly, some level of minimal cognitive diversity in the technical backgrounds of the team might be required (Aggarwal \& Woolley, 2019), for example, technical professions with slightly different specializations. Subsequently, we posit the following hypothesis.

H2b: NVT members with technical backgrounds are more likely to move jointly after a new venture dissolves than a team of people with other qualifications. 


\subsubsection{Prior joint work experience and NVT comobility}

New ventures are often formed by individuals with shared prior work experience (Klotz et al., 2014). NVTs where such ties exist are better at attracting venture capital (Roure \& Maidique, 1986), have more speed in the delivery of new products (Beckman, 2006; Beckman et al., 2007), demonstrate higher levels of sales (Eisenhardt \& Schoonhoven, 1990), deliver a higher return on assets (Zheng et al., 2016), and have a higher likelihood of survival (Coad \& Timmermans, 2014).

Zheng (2012) assigns a performance premium that can be attributed to the above process of transactive memory system and team-specific human capital. This might be an alternative or possibly additional motive for them to end collaboration in subsequent employment relations. Given the uncertain nature of establishing a new venture, these benefits might not have fully materialized in the new ventures. However, this does not deter NVT members from pursuing subsequent career opportunities that allow them to take advantage of this prior joint work experience.

Alternatively, and in line with a more nuanced picture that comobility might not solely be driven by benefits, the fact that comobility has occurred previously might also be an indication that the NVT members face mobility constraints that tie them together. Regardless of the motives, we adopt the following hypothesis.

H3: NVT members who previously shared working experience are more likely to comove following the dissolution of the new venture.

\subsubsection{Comobility of NVT and new venture performance}

Numerous studies on new venture dissolution have demonstrated the complexity of motives underlying the closure of new ventures as well as the nature of the closure (Cope, 2011; Ucbasaran et al., 2013; Wennberg \& DeTienne, 2014). More specifically, not all dissolved ventures are unequivocal failures as onethird of the new ventures that shut down are identified as being successful at the time of closure (Head, 2003; Ucbasaran et al., 2013).
The fact that the new venture has demonstrated a relatively strong performance might indicate some value in future collaboration. In addition to sending a signal to potential future employers, it might also maintain confidence internally in the NVT to continue their co-working relationship. Regardless of the career trajectory these individuals choose, we thus argue that they have a higher probability to comove. Thus, we hypothesize:

H4: Comobility among NVT members is more likely to occur when the new venture demonstrated higher pre-dissolution performance.

\section{Method}

\subsection{Data and context}

In testing these hypotheses, we rely on data from the Danish register, often referred to by its Danish acronym IDA. The IDA is constructed from merging several government registers that provide detailed information on all individuals and firms in Denmark. First, we rely on the entrepreneurship register, which provides us with an overview of all new ventures, including their founders. Second, we use the employer-employee register to identify the career history of individuals with a formal attachment to these new ventures, either as a founder, as an owner, or as an employee. Third, the person register allows us to identify individual characteristics like age, gender, educational background, and family relations. Finally, the firm register enables us to obtain access to accounting information and overall firm characteristics, such as date of founding, industry, and geography.

The longitudinal and universal nature of the register provides insights into the establishment, growth, and survival of new ventures, as well as how the decision to start or join a new venture affects the individual. Consequently, IDA is a database frequently used by entrepreneurship researchers also because the Danish entrepreneurial context shows much similarity to those of other countries in northern Europe (Dahl \& Sorenson, 2012). This research covers a broad spectrum of topics, such as team composition (Coad \& Timmermans, 2014; Kaiser \& Müller, 2015) and early hiring decisions (Coad et al., 2017), 
entrepreneurship and wages (Burton et al., 2018), gender wage gap in entrepreneurship (Rocha \& Van Praag, 2020), and learning from failure (Nielsen \& Sarasvathy, 2016).

The register is well-suited to our analysis. First, the longitudinal nature of the database provides us with the ability to identify new ventures that are eventually terminated. Second, the register has a detailed record on all individuals with a formal attachment to a terminated business, something that is notoriously difficult to identify. Third, we can follow the career trajectories of individuals and identify co-worker relationships. Finally, the unique firm and workplace identification numbers, in combination with the new firm registry, allow us to identify new ventures, the year in which the ventures were established, and the year in which they terminated their activities.

\subsection{Sample identification}

\subsubsection{Dissolved new ventures}

For our analysis, we are restricted to new ventures established between 2001 and 2006. The lower bound is due to a structural break in the data, and the upper year restriction is a result of data availability. To create a sample of dissolved new ventures, we select new ventures that were deregistered within 5 years of founding $(n=5,215)$. In addition, we select teambased new ventures with up to 10 employees in the founding year, as larger teams in most cases appear not to be truly new ventures $(n=3,673)$. By following the identification numbers of workplaces and firms, we also exclude those ventures that appear to be active in the year prior to their formal establishment and the years following the deregistration $(n=3,641)$. In addition, we remove all new ventures with missing firm-level information $(n=3,616)$.

The sample reduces further as a result of missing workplace and individual-level information on the NVT members $(n=3,496)$. Finally, we exclude all new ventures in public industries or heavily publicregulated industries. Following these strict selection criteria, we identify 3,330 team-based new ventures that ceased operations within 5 years of their founding. Please note that requirements on NVT membership and the ability to identify the career of these workers adds additional sample restrictions.
Table 1 Labor market status of NVT members in the year following the new venture dissolution

\begin{tabular}{llr}
\hline $\begin{array}{l}\text { Labor market status in the year after } \\
\text { new venture dissolution }\end{array}$ & Count & Percentage \\
\hline Wage earner/entrepreneur & 15,038 & $81.25 \%$ \\
Unemployed/leave of absence & 1,240 & $6.70 \%$ \\
Outside the labor force & 1,443 & $7.80 \%$ \\
Unknown (i.e., migrated, missing, died) & 788 & $4.26 \%$ \\
Total & $\mathbf{1 8 , 5 0 9}$ & $\mathbf{1 0 0 . 0 0 \%}$ \\
\hline
\end{tabular}

\subsubsection{New venture team members}

To operationalize our NVT concept, we align closely with the work of Gartner et al. (1994) and conceptualize the NVT as founders and (early) joiners (Roach \& Sauermann, 2015). Due to data restrictions, we only identify individuals with a formal attachment to the new venture in the role of founder, employer, owner, or employee. All those affiliated with the new venture up to its closure are regarded as NVT members; however, we create a dummy variable that indicates if the individual was an NVT member in the year of founding. As an additional criterion, an NVT member must be present with at least one other member during the observation period to ensure that they are collaborators. This criterion resulted in the exclusion of 60 individuals, leading to a final sample of 18,509 NVT members.

NVT comobility can only be determined for NVT members that remain active on the labor market as a founder/owner, employer, or employee. Individuals who in the year following the dissolution are unemployed or otherwise outside the labor market are excluded from the sample. IDA allows us to identify the labor market status of all NVT members, and we identify $15,038(81.25 \%)$ NVT members who are still active in the year following the dissolution of the new venture (see Table 1). ${ }^{1}$ These findings mirror the work by Jenkins and McKelvie (2017), who find that the majority of owner-managers remain active

\footnotetext{
1 The remaining $18.75 \%$ can be classified as follows: Just over $6 \%$ are registered as unemployed or on sick leave. Close to $8 \%$ of the NVT members are outside the labor force. Based on the information in the register, we identify that the majority of NVT members below the age of 25 are pursuing an education and the majority of NVT members over 60 are retired. Approximately $4 \%$ are no longer registered in Denmark, which means they either left the country, passed away, or are missing.
} 
in the labor market following the closure of the new venture.

We remove all NVT members that join an unidentifiable workplace. Finally, we observe 1,618 NVT members who return to, or never left, the employer they worked for prior to the establishment of the new venture. We are unable to identify whether this type of return really meant a move and to remove these individuals from our sample. Based on these criteria, we identify 11,903 NVT members who are affiliated with 2,403 new ventures.

\subsubsection{Dependent variable: comobility of NVT members}

Our variable of interest is NVT members' comobility. We apply a strict definition of comobility where the NVT members re-appear in the same workplace. As an indicator for comobility, we create a dummy variable with the value "one" when comobility occurs and "zero" otherwise. To identify re-entry into entrepreneurship, we use the entrepreneurship register to see if the new workplace is a newly established venture.

To understand the determinants of comobility, we focus on the relationship between individual pairs or dyads. There are conceptual and methodological motives to focus on dyads. First, dyads provide us with insights on the nature of the relationship between individuals. Individual-level analysis will not capture this effect. Focusing on dyads is methodologically meaningful (Coad \& Timmermans, 2014; Harper, 2008). Dyads provide a straightforward relationship. When moving to larger network constructs, for example triads, the measurement becomes increasingly more complex. This is particularly valid when investigating mobility patterns, as mobility patterns of individuals within a team differ. For example, in a team of three NVT members, only two might comove, while the third follows a different career path. Creating a team-level comobility measure, such as the share of comovers, and investigating how teamlevel characteristics determine this comobility rate become less meaningful. To illustrate, in large teams, we identify a certain level of homogeneity among team members, but we cannot determine if those that comove reflect the homogeneity in the NVT. Second, we are confronted with subgroups of comovers who move to different employers. The motives for each subgroup to comove might differ, and each subgroup might have different unit-level characteristics.

Dyads are created by linking each NVT member with another, irrespective of comobility, making the total number of dyads per new venture

$\frac{n_{j} \cdot\left(n_{j}-1\right)}{2}$,

where $n_{j}$ is the number of NVT members in a new venture $j$. In total, our sample of NVT members yields 36,398 unique dyads.

\subsubsection{Independent variables dyad-level characteristics}

We create a set of dyad-level indicators on personlevel characteristics: gender, age, and nationality. For gender, we create dummy variables for all-male dyads and all-female dyads, the mixed-gender dyad being the omitted category. We create a measure for the average age, and the age dispersion is measured by the absolute age difference in the dyad. For nationality, we make a distinction between Danish and foreign citizenship, creating a dummy variable for allDane dyads and all-foreign dyads, the Danish-foreign dyad being the omitted category.

For human capital characteristics, we rely on the educational background. First, we create a variable indicating the average education level, measured in the years of education following basic education (i.e., upper secondary education or vocational training and beyond). Second, we create a measure indicating the disparity in education level, and we measure this disparity by the absolute difference in years of education. In addition, we create a dummy variable indicating whether the dyad includes one or two individuals with a college degree, technical or engineering degree, or business degree.

To measure prior joint work experience, we identify the career trajectory of NVT members and identify the workplace of all NVT members in the year before the establishment of the new venture. We create a dummy variable with the value "1" whenever the individuals in the dyad worked at the same workplace prior to establishing the new venture; the dummy variable receives a " 0 " otherwise.

Finally, we define a set of dyad-level characteristics that function as controls. The first controls are 
the length of NVT membership - that is, whether both team members were members in the year of founding, whether only one individual was a member in the year of founding, or whether both joined the team in later years. We develop a similar variable but focuses on whether members were present in the last observation prior to the dissolution. We also identify whether one person in the dyad is registered as the founder/owner of the business. Finally, we include a dummy variable whether the dyad is a family relationship.

\subsubsection{New venture and new venture team characteristics}

We also create a set of variables based on the characteristics of the new venture. This includes the size at founding, year of founding, geographic location of the new venture, firm age upon closure, and industry. For industry, we identify the different sectors within the NACE rev2 industrial classification system. ${ }^{2}$ To create a distinction in the broad sector of manufacturing industries, we divide this category into high- and low-tech industries. For a separate analysis, we create a subsample of new ventures that are active within high-tech and knowledge-intensive business services. We create a dummy variable when the new venture is a family firm. We define a family firm as a new venture when two members of the same family were present in the year of founding.

Finally, we include an indicator on how the firm performed prior to closure. As mentioned previously, research on new venture exit demonstrates that exits in general, and thereby closures of new ventures, are not unequivocally regarded as "failures." The IDA does not provide us with information on the motives for the dissolution, but the performance and measures in revenue up to closure might provide us with some indication of the overall state of affairs prior to dissolution.

\footnotetext{
$\overline{2}$ These sectors are manufacturing, construction, wholesale and retail, accommodation and food services, transportation and storage, information and communication, financial and insurance activities, real estate activities, professional, scientific and technical activities, and administrative and support service activities.
}

\section{Results}

Table 2 presents an overview of the descriptive statistics and elaborates on differences in means between comoving and non-comoving dyads. The table with correlations is included in the Appendix. Based on our measure for comobility, we identify 2,870 comoving dyads or $7.9 \%$ of all identified dyads. Breaking down these dyads into unique individuals, there are 2,174 individual comovers; thus, the individual rate of comobility among NVT members is approximately $18.3 \%$. This seems to confirm our expectation that comobility among NVTs is a common phenomenon.

Turning to some of our most salient variables, we observe an overrepresentation of males, resulting in an overrepresentation of male dyads. The share of male dyads is significantly larger among comovers. The average age of individuals in the dyads is around 28.6, but comoving dyads are on average older and have a larger age difference compared with non-comoving dyads. Dyads consisting of foreign citizens are overrepresented among our comovers.

In terms of educational background, dyads with a college degree are relatively more common in our comoving dyads. There is no significant difference in education levels. There are relatively more dyads with at least one NVT member with a technical and/ or business degree among the comoving dyads; this also holds for dyads that consist of only technical or business degrees.

When the dyad is observed in the year up to closure, they are also more likely to continue their work relationship post-dissolution. Furthermore, the founder is more often likely to be part of the comoving dyad. Comobility is more frequent when the dyad worked in a knowledge-intensive or high-tech industry.

Six percent of the dyads are with prior joint work. When breaking down the dyads into individual observations, we find that $16 \%$ have shared prior work experience with one of the other NVT members. The share of prior joint work experience dyads is significantly larger among comovers. Finally, comobility is significantly larger among dyads that experienced higher levels of sales revenue in the year prior to dissolution. 
Table 2 Descriptive statistics and difference-in-means test for dyads $(n=36,398)$

\begin{tabular}{|c|c|c|c|c|c|}
\hline \multirow[t]{2}{*}{ Variable } & \multirow[t]{2}{*}{ Description } & \multirow[t]{2}{*}{ Mean } & \multirow[t]{2}{*}{ SD } & \multicolumn{2}{|c|}{ Difference-in-means comobility } \\
\hline & & & & No $(n=33,528)$ & Yes $(n=2,870)$ \\
\hline Male dyad & $\begin{array}{l}\text { Both NVT members in the dyad are } \\
\text { male }\end{array}$ & 0.413 & 0.492 & 0.405 & 0.499 \\
\hline Female dyad & $\begin{array}{l}\text { Both NVT members in the dyad are } \\
\text { female }\end{array}$ & 0.285 & 0.452 & 0.289 & 0.238 \\
\hline Mix gender dyad & Dyad with male and female & 0.302 & 0.459 & 0.305 & 0.262 \\
\hline Average age dyad & $\begin{array}{l}\text { The avereage age of the NVT members } \\
\text { in the dyad }\end{array}$ & 28.632 & 9.371 & 28.289 & 32.643 \\
\hline Age difference dyad & $\begin{array}{l}\text { The absolute age difference NVT mem- } \\
\text { bers in years }\end{array}$ & 10.122 & 9.389 & 10.083 & 10.580 \\
\hline Dane dyad & $\begin{array}{l}\text { Both NVT members have the Danish } \\
\text { nationality }\end{array}$ & 0.856 & 0.351 & 0.856 & 0.863 \\
\hline Foreign dyad & $\begin{array}{l}\text { Both NVT members have a non-Danish } \\
\text { nationality }\end{array}$ & 0.041 & 0.198 & 0.040 & 0.051 \\
\hline Dane-foreign dyad & $\begin{array}{l}\text { Dyad with Danes and non-Danes } \\
\text { nationality }\end{array}$ & 0.103 & 0.303 & 0.104 & 0.086 \\
\hline Family dyad & $\begin{array}{l}\text { Both NVT members are part of the } \\
\text { same family }\end{array}$ & 0.022 & 0.146 & 0.019 & 0.056 \\
\hline Prior joined experience & $\begin{array}{l}\text { Both NVT members worked at the } \\
\text { same workplace prior to starting the } \\
\text { new venture }\end{array}$ & 0.064 & 0.245 & 0.057 & 0.148 \\
\hline Average education year dyad & $\begin{array}{l}\text { The average years of education of the } \\
\text { NVT members in the dyad }\end{array}$ & 1.428 & 1.361 & 1.401 & 1.747 \\
\hline Education year difference dyad & $\begin{array}{l}\text { The absolute difference in years of } \\
\text { education between NVT members in } \\
\text { the dyad }\end{array}$ & 1.393 & 1.509 & 1.396 & 1.357 \\
\hline 1 NVT member with college degree & $\begin{array}{l}\text { Only one of the NVT members has a } \\
\text { college degree (or higher) }\end{array}$ & 0.155 & 0.362 & 0.156 & 0.145 \\
\hline $\begin{array}{l}1 \text { NVT member with technical educa- } \\
\text { tion }\end{array}$ & $\begin{array}{l}\text { Only one of the NVT members has an } \\
\text { education background in engineering }\end{array}$ & 0.176 & 0.380 & 0.172 & 0.214 \\
\hline $\begin{array}{l}1 \text { NVT member with business educa- } \\
\text { tion }\end{array}$ & $\begin{array}{l}\text { Only one of the NVT members has an } \\
\text { education background in business } \\
\text { and/or economics }\end{array}$ & 0.203 & 0.403 & 0.202 & 0.221 \\
\hline College degree dyad & $\begin{array}{l}\text { Both NVT members have a college } \\
\text { degree }\end{array}$ & 0.032 & 0.177 & 0.030 & 0.055 \\
\hline Technical/engineering education dyad & $\begin{array}{l}\text { Both NVT members have an educa- } \\
\text { tional background in Engineering }\end{array}$ & 0.074 & 0.262 & 0.069 & 0.127 \\
\hline Business/administration dyad & $\begin{array}{l}\text { Both NVT members have an educa- } \\
\text { tional background in Business and } \\
\text { Economics }\end{array}$ & 0.033 & 0.178 & 0.032 & 0.045 \\
\hline 1 NVT member present at end & $\begin{array}{l}\text { Only one of the NVT members was } \\
\text { present in the year prior to new } \\
\text { venture exit }\end{array}$ & 0.206 & 0.404 & 0.214 & 0.110 \\
\hline $1 \mathrm{NVT}$ member present at start & $\begin{array}{l}\text { Only one of the NVT members was } \\
\text { present in the year of new venture } \\
\text { founding }\end{array}$ & 0.280 & 0.449 & 0.278 & 0.296 \\
\hline End dyad & $\begin{array}{l}\text { Both NVT members where present } \\
\text { in the final observation before new } \\
\text { venture closure }\end{array}$ & 0.260 & 0.438 & 0.231 & 0.590 \\
\hline
\end{tabular}


Table 2 (continued)

\begin{tabular}{|c|c|c|c|c|c|}
\hline \multirow[t]{2}{*}{ Variable } & \multirow[t]{2}{*}{ Description } & \multirow[t]{2}{*}{ Mean } & \multirow[t]{2}{*}{ SD } & \multicolumn{2}{|c|}{ Difference-in-means comobility } \\
\hline & & & & No $(n=33,528)$ & Yes $(n=2,870)$ \\
\hline Start dyad & $\begin{array}{l}\text { Both NVT members where present in } \\
\text { the first observation following firm } \\
\text { founding }\end{array}$ & 0.262 & 0.440 & 0.267 & 0.208 \\
\hline Founder dyad & $\begin{array}{c}\text { The registered founder/owner of the } \\
\text { new venture is part of the dyad }\end{array}$ & 0.196 & 0.397 & 0.192 & 0.242 \\
\hline Copenhagen & $\begin{array}{l}\text { The new venture was located in the } \\
\text { Larger Copenhagen Area }\end{array}$ & 0.250 & 0.433 & 0.251 & 0.239 \\
\hline Family firm & $\begin{array}{l}\text { The new venture is considered to be a } \\
\text { family firm }\end{array}$ & 0.236 & 0.425 & 0.241 & 0.187 \\
\hline Knowledge-intensive industry & $\begin{array}{l}\text { The new venture is active in a knowl- } \\
\text { edge intensive industry }\end{array}$ & 0.122 & 0.328 & 0.118 & 0.175 \\
\hline Last-year turnover (10.000 DKK) & $\begin{array}{l}\text { Turnover in the year prior to new } \\
\text { venture exit }\end{array}$ & 33.894 & 60.984 & 31.105 & 66.488 \\
\hline
\end{tabular}

Values in bold are signicantly higher on the $5 \%$ level

\subsection{NVT comobility and entrepreneurship}

As shown in Table 3, comovers are affiliated with 783 unique post-dissolution firms and 177 (22.6\%) are new ventures. This stands in stark contrast with the number of new ventures that non-comovers are associated with (which is 619 or $9.4 \%$ ). On the individual level, just over $22 \%$ of comovers are affiliated with a new venture compared with $6.5 \%$ of non-comovers. Although $18 \%$ of NVT members are comovers, they make up $43 \%$ of NVT members that are part of a newly established venture following the dissolution. Thus, they appear to be responsible for a relatively large share of new businesses, potentially as serial or habitual NVTs.

\subsection{Logit regression analysis}

The results of the logit and multinomial logit regression analysis on the determinants of comobility and subsequent re-entry into entrepreneurship are presented in Table 4. This table contains several models where we create a set of subsamples that allow us to explore various aspects of the NVT comobility phenomenon. Models 1 and 2 present the logistic regression analysis for the full sample. The difference
Table 3 Destination of comovers and noncomovers

\begin{tabular}{|c|c|c|c|c|c|}
\hline & No. of firm & & & & \\
\hline & Comovers & & Non-comovers & & Total \\
\hline \multirow[t]{2}{*}{ Established firms } & 606 & $9.2 \%$ & 5,951 & $90.8 \%$ & 6,557 \\
\hline & $77.4 \%$ & & $90.6 \%$ & & $89.2 \%$ \\
\hline \multirow[t]{2}{*}{ New ventures } & 177 & $22.2 \%$ & 619 & $77.8 \%$ & 796 \\
\hline & $22.6 \%$ & & $9.4 \%$ & & $10.8 \%$ \\
\hline \multirow[t]{3}{*}{ Total } & 783 & $10.6 \%$ & 6,570 & $89.4 \%$ & 7,353 \\
\hline & No. of indi & & & & \\
\hline & Comovers & & Non-comovers & & Total \\
\hline \multirow[t]{2}{*}{ Established firms } & 1,693 & $15.7 \%$ & 9,093 & $84.3 \%$ & 10,786 \\
\hline & $77.9 \%$ & & $93.5 \%$ & & $90.6 \%$ \\
\hline \multirow[t]{2}{*}{ New ventures } & 481 & $43.1 \%$ & 636 & $56.9 \%$ & 1,117 \\
\hline & $22.1 \%$ & & $6.5 \%$ & & $9.4 \%$ \\
\hline Total & 2,174 & $18.3 \%$ & 9,729 & $81.7 \%$ & 11,903 \\
\hline
\end{tabular}


between these two models is that in model 1, we only control if the comoving dyad works for a new venture in a knowledge-intensive industry, while model 2 includes unreported dummy variables for our more detailed industry classification. Model 3 shows the result of the multinomial regression analysis. Here, we separate the destination for comobility into entrepreneurship and other employment.

Let us compare our hypothesis to the findings in these three models, where we find partial confirmation for Hypothesis 1. Comobility appears to be stronger among same-gender dyads, but it is worth noting that this effect is weaker in female dyads. Compared to the baseline probability, where $7.9 \%$ of dyads comove, the probability that all-male and all-female dyads comove lies respectively 1.3 and 1.2 percentage points (p.p.) higher (based on the coefficients of model 2). ${ }^{3}$ Concerning re-entry into entrepreneurship, we observe that male dyads tend to comove to other forms of employment, while female dyads comove into entrepreneurship. In the other measures of homophily, we observe that similarity in age is associated with higher probabilities of comobility, and when this occurs, it tends to be in other forms of employment. For homophily, in terms of nationality, we observe that there is no effect of an all-Dane dyad being less likely to comove. On the other hand, the probability that comobility occurs among foreign dyads is 3.2 p.p. higher compared with our baseline probability. It might appear that comobility into entrepreneurship can partially be explained by necessity. Dyads of foreign citizens, who tend to be more marginalized in the labor market, have a higher probability of comoving into entrepreneurship.

When we turn our attention to our human capital variables, we observe that the presence of one NVT member with a college degree, technical, or business education increased the probability that comobility occurs with respectively $1.6,1.0$, and 1.1 percentage

\footnotetext{
${ }^{3}$ For male dyads, the baseline estimated probability is $7.9 \%$, which is converted to a baseline odds ratio of $0.079 / 0.921=0.086$. Given the odds ratio for our male dyads of $1.18\left(\mathrm{e}^{\wedge} 0.166\right)$, we obtain the odds for this dyad as $0.086 \times 1.18=0.101$. Converting the new odds back to probabilities yields $0.101 / 1+0.101=0.092$. Thus, male dyads have a probability of approximately $9.2 \%$ compared to the baseline of $7.9 \%$, meaning a 1.3 p.p. increase in the probability that comobility occurs.
}

points. The most pronounced effect is observed in the similarity in these dyads as the probability increases with $8.5,4.8$, and 1.7 p.p. for college dyads, technical dyads, and business administration dyads, respectively. ${ }^{4}$ This provides an indication that when the NVT members in the dyad are associated with knowledge work and/or technical work, it increases the probability of comobility providing support for Hypotheses $2 \mathrm{a}$ and $2 \mathrm{~b}$. Given that model 1 demonstrates that dyads from knowledge-intensive and hightech industries have a 3.7 p.p. higher probability for comobility, we obtain additional confirmation on this point.

Also, in the case of educational background, there is some indication that comobility into entrepreneurship might be driven by necessity. First, we observe that higher levels of education are associated with a lower probability to comove into entrepreneurship. Otherwise, higher educated and skilled workers are more likely to comove into an existing form of employment. The exception here are technical workers who appear to be more prone to continue their collaboration, regardless in which setting they operate. These findings mirror those of Marx and Timmermans (2017) and might be an indication of how the cognitive interdependence of technical workers possibly constrain the mobility of these workers.

Hypothesis 3 can also be confirmed, prior joined work experience also demonstrates to have a positive effect on the probability of comobility, an increase of 10 p.p. compared with the baseline, following the closure of the new venture. It is also an important determinant in the decision to re-enter into entrepreneurship but even more so for entering another form of employment. This demonstrates that some individuals tend to follow each other in their career trajectory. Finally, we also find confirmation of our last hypothesis. Hypothesis 4 shows that as in all models, a higher performance increases the probability that comobility occurs with 3.4 p.p. per extra $1 \mathrm{mln}$ NOK of revenue (approximately 100.000 USD). A higher level of performance increases the probability of comobility, especially re-entry into entrepreneurship.

\footnotetext{
${ }^{4}$ A lower probability for dyads with a business administrative background might be explained by the fact that there is less interdependence and joined specialization in the task an individual with the task this type of worker conducts compared to, for example, technical workers.
} 
Table 4 Logistic regression results on determinants of comobility

\begin{tabular}{|c|c|c|c|c|c|c|c|}
\hline \multirow{3}{*}{ Sample } & \multirow{3}{*}{$\begin{array}{l}\text { Model } 1 \\
\text { All dyads } \\
\text { Comove }\end{array}$} & \multirow{3}{*}{$\begin{array}{l}\text { Model } 2 \\
\text { All dyads } \\
\text { Comove }\end{array}$} & \multirow{2}{*}{\multicolumn{2}{|c|}{$\frac{\text { Model } 3}{\text { All dyads (mlogit) }}$}} & \multirow{3}{*}{$\begin{array}{l}\text { Model } 4 \\
\text { Knowledge-intensive } \\
\text { and high-tech industries } \\
\text { Comove }\end{array}$} & \multirow{2}{*}{\multicolumn{2}{|c|}{$\begin{array}{l}\text { Model } 5 \\
\text { Knowledge-intensive } \\
\text { and high-tech industries } \\
\text { (mlogit) }\end{array}$}} \\
\hline & & & & & & & \\
\hline & & & $\begin{array}{l}\text { Comove } \\
\text { Non_e'ship }\end{array}$ & $\begin{array}{l}\text { Comove } \\
\text { e'ship }\end{array}$ & & $\begin{array}{l}\text { Comove } \\
\text { Non_e'ship }\end{array}$ & $\begin{array}{l}\text { Comove } \\
\text { e'ship }\end{array}$ \\
\hline Male dyad & $\begin{array}{l}0.261 * * * \\
(0.05)\end{array}$ & $\begin{array}{l}0.166^{* * * *} \\
(0.06)\end{array}$ & $\begin{array}{l}0.185^{* * * *} \\
(0.06)\end{array}$ & $\begin{array}{l}0.097 \\
(0.08)\end{array}$ & $\begin{array}{l}0.369 * * * \\
(0.14)\end{array}$ & $\begin{array}{l}0.491 * * * \\
(0.18)\end{array}$ & $\begin{array}{c}0.224 \\
(0.21)\end{array}$ \\
\hline Female dyad & $\begin{array}{l}0.081 \\
(0.06)\end{array}$ & $\begin{array}{l}0.153^{* * *} \\
(0.06)\end{array}$ & $\begin{array}{l}0.140 * \\
(0.08)\end{array}$ & $\begin{array}{l}0.189 * * \\
(0.09)\end{array}$ & $\begin{array}{l}-0.039 \\
(0.24)\end{array}$ & $\begin{array}{c}0.155 \\
(0.28))\end{array}$ & $\begin{array}{c}-0.474 \\
(0.48\end{array}$ \\
\hline Average age dyad & $\begin{array}{l}0.037 * * * \\
(0.00)\end{array}$ & $\begin{array}{l}0.028 * * * \\
(0.00)\end{array}$ & $\begin{array}{l}0.020 * * * \\
(0.00)\end{array}$ & $\begin{array}{l}0.041^{* * * *} \\
(0.01)\end{array}$ & $\begin{array}{l}0.050 * * * \\
(0.01)\end{array}$ & $\begin{array}{l}0.050 * * * \\
(0.01)\end{array}$ & $\begin{array}{l}0.031 * \\
(0.02)\end{array}$ \\
\hline Age difference dyad & $\begin{array}{l}-0.006^{* *} \\
(0.00)\end{array}$ & $\begin{array}{l}-0.005^{*} \\
(0.00)\end{array}$ & $\begin{array}{l}-0.010^{* *} \\
(0.00)\end{array}$ & $\begin{array}{l}0.002 * \\
(0.01)\end{array}$ & $\begin{array}{l}-0.019 * * \\
(0.01)\end{array}$ & $\begin{array}{c}-0.018^{*} \\
(0.01)\end{array}$ & $\begin{array}{c}-0.018 \\
(0.01)\end{array}$ \\
\hline Dane dyad & $\begin{array}{l}-0.103 \\
(0.07)\end{array}$ & $\begin{array}{l}-0.122 * \\
(0.07)\end{array}$ & $\begin{array}{l}-0.177 * \\
(0.09)\end{array}$ & $\begin{array}{l}-0.055 \\
(0.11)\end{array}$ & $\begin{array}{l}0.308 \\
(0.22)\end{array}$ & $\begin{array}{r}0.209 \\
(0.23)\end{array}$ & $\begin{array}{c}0.440 \\
(0.44)\end{array}$ \\
\hline Foreign dyad & $\begin{array}{l}0.321 * * \\
(0.12)\end{array}$ & $\begin{array}{l}0.367 * * * \\
(0.12)\end{array}$ & $\begin{array}{l}0.174 \\
(0.15)\end{array}$ & $\begin{array}{l}0.567 * * * \\
(0.18)\end{array}$ & $\begin{array}{l}0.256 \\
(0.43)\end{array}$ & $\begin{array}{c}0.336 \\
(0.50)\end{array}$ & $\begin{array}{r}0.715 \\
(0.73)\end{array}$ \\
\hline $\begin{array}{l}\text { Education year differ- } \\
\text { ence dyad }\end{array}$ & $\begin{array}{l}-0.029 * \\
(0.02)\end{array}$ & $\begin{array}{l}-0.045^{* * *} \\
(0.02)\end{array}$ & $\begin{array}{l}-0.058 * * * \\
(0.02)\end{array}$ & $\begin{array}{l}-0.03 \\
(0.03)\end{array}$ & $(0.04)$ & $(0.05)$ & $(0.07)$ \\
\hline $\begin{array}{l}\text { Average education year } \\
\text { dyad }\end{array}$ & $\begin{array}{l}-0.157 * * * \\
(0.03)\end{array}$ & $\begin{array}{l}-0.140 * * * \\
(0.03)\end{array}$ & $\begin{array}{l}-0.041 \\
(0.03)\end{array}$ & $\begin{array}{l}-0.216^{* * *} \\
(0.04)\end{array}$ & $(0.07)$ & $(0.09)$ & $(0.10)$ \\
\hline $\begin{array}{l}1 \text { NVT member with } \\
\text { college degree }\end{array}$ & $(0.07)$ & $0.200 * * *$ & $0.317 * * *$ & $\begin{array}{l}-0.007 \\
(0.11)\end{array}$ & $\begin{array}{l}-0.507 * * * \\
(0.19)\end{array}$ & $(0.26)$ & $\begin{array}{c}-1.549 * * * \\
(0.31)\end{array}$ \\
\hline $\begin{array}{l}1 \text { NVT member with } \\
\text { technical education }\end{array}$ & $0.162^{* *}$ & $0.126^{*}$ & $\begin{array}{l}0.058 \\
(0.09)\end{array}$ & $(0.10)$ & $\begin{array}{l}0.065 \\
(0.17)\end{array}$ & $\begin{array}{c}-0.098 \\
(0.25)\end{array}$ & $\begin{array}{l}0.126 \\
(0.27)\end{array}$ \\
\hline $\begin{array}{l}1 \text { NVT member with } \\
\text { business education }\end{array}$ & $0.155^{* *}$ & $0.139 * *$ & $(0.08)$ & $(0.09)$ & $\begin{array}{l}-0.380 * * \\
(0.15)\end{array}$ & $\begin{array}{r}-0.169 \\
(0.19)\end{array}$ & $\begin{array}{c}-0.861 * * * \\
(0.24)\end{array}$ \\
\hline College degree dyad & $\begin{array}{l}0.838 * * * \\
(0.13)\end{array}$ & $\begin{array}{l}0.829 * * * \\
(0.13)\end{array}$ & $\begin{array}{l}1.121 * * * \\
(0.14)\end{array}$ & $\begin{array}{l}-0.007 \\
(0.29)\end{array}$ & $\begin{array}{l}-0.679 * * \\
(0.28)\end{array}$ & $\begin{array}{c}-0.007 \\
(0.38)\end{array}$ & $\begin{array}{l}-2.615^{* * * *} \\
(0.85)\end{array}$ \\
\hline $\begin{array}{l}\text { Technical/engineering } \\
\text { education dyad }\end{array}$ & $0.577 * * *$ & $0.526 * * *$ & $0.398 * * *$ & $\begin{array}{l}0.585^{* * * *} \\
(0.16)\end{array}$ & $0.759 * * *$ & $0.740 * * *$ & $\begin{array}{l}0.356 \\
(0.42)\end{array}$ \\
\hline $\begin{array}{l}\text { Business/administration } \\
\text { dyad }\end{array}$ & $0.302 * *$ & $0.216^{*}$ & 0.215 & $(0.19)$ & $\begin{array}{l}-0.401 \\
(0.26)\end{array}$ & $\begin{array}{c}-0.101 \\
(0.31)\end{array}$ & $\begin{array}{c}-0.953 * * \\
(0.42)\end{array}$ \\
\hline $\begin{array}{l}\text { Prior joined experience } \\
\text { dyad }\end{array}$ & $0.933 * * *$ & $0.936 * * *$ & $1.115^{* * *}$ & $0.675 * * *$ & $1.170 * * *$ & $1.283 * * *$ & $\begin{array}{l}1.055 * * * \\
(0.33)\end{array}$ \\
\hline Family dyad & $\begin{array}{l}1.150^{* * * *} \\
(0.12)\end{array}$ & $\begin{array}{l}1.148 * * * \\
(0.12)\end{array}$ & $\begin{array}{l}1.225^{* * * *} \\
(0.14)\end{array}$ & $\begin{array}{l}1.059 * * * \\
(0.17)\end{array}$ & $\begin{array}{l}0.243 \\
(0.56)\end{array}$ & $\begin{array}{l}0.366 \\
(0.81)\end{array}$ & $\begin{array}{r}0.447 \\
(0.76)\end{array}$ \\
\hline $\begin{array}{l}1 \text { NVT member present } \\
\text { at end }\end{array}$ & $-0.167 * *$ & $-0.168^{* *}$ & $-0.195 * *$ & -0.66 & $-1.332 * * *$ & $-1.373 * * *$ & $-1.421 * * *$ \\
\hline
\end{tabular}


Table 4 (continued)

\begin{tabular}{|c|c|c|c|c|c|c|c|}
\hline \multirow{3}{*}{ Sample } & \multirow{3}{*}{$\begin{array}{l}\text { Model } 1 \\
\text { All dyads } \\
\text { Comove }\end{array}$} & \multirow{3}{*}{$\begin{array}{l}\text { Model } 2 \\
\text { All dyads } \\
\text { Comove }\end{array}$} & \multirow{2}{*}{\multicolumn{2}{|c|}{$\frac{\text { Model } 3}{\text { All dyads (mlogit) }}$}} & \multirow{3}{*}{$\begin{array}{l}\text { Model } 4 \\
\text { Knowledge-intensive } \\
\text { and high-tech industries } \\
\text { Comove }\end{array}$} & \multirow{2}{*}{\multicolumn{2}{|c|}{$\begin{array}{l}\text { Model } 5 \\
\text { Knowledge-intensive } \\
\text { and high-tech industries } \\
\text { (mlogit) }\end{array}$}} \\
\hline & & & & & & & \\
\hline & & & $\begin{array}{l}\text { Comove } \\
\text { Non_e'ship }\end{array}$ & $\begin{array}{l}\text { Comove } \\
\text { e'ship }\end{array}$ & & $\begin{array}{l}\text { Comove } \\
\text { Non_e'ship }\end{array}$ & $\begin{array}{l}\text { Comove } \\
\text { e'ship }\end{array}$ \\
\hline & $(0.07)$ & $(0.07)$ & $(0.08)$ & $(0.11)$ & $(0.28)$ & $(0.34)$ & $(0.54)$ \\
\hline \multirow{2}{*}{$\begin{array}{l}1 \mathrm{NVT} \text { member present } \\
\text { at start }\end{array}$} & 0.085 & $0.183 * * *$ & $0.152 * *$ & $0.203 * *$ & 0.224 & 0.238 & -0.175 \\
\hline & $(0.06)$ & $(0.06)$ & $(0.08)$ & $(0.09)$ & $(0.16)$ & $(0.19)$ & $(0.29)$ \\
\hline \multirow[t]{2}{*}{ End dyad } & $1.376 * * *$ & $1.330 * * *$ & $1.164 * * *$ & $1.585 * * *$ & $1.076 * * *$ & $0.858 * * *$ & $0.794 * * *$ \\
\hline & $(0.05)$ & $(0.05)$ & $(0.06)$ & $(0.08)$ & $(0.17)$ & $(0.19)$ & $(0.39)$ \\
\hline \multirow[t]{2}{*}{ Start dyad } & $-0.244 * *$ & -0.125 & -0.169 & -0.063 & $-0.476^{* *}$ & $-0.476^{*}$ & $-0.779 * *$ \\
\hline & $(0.08)$ & $(0.08)$ & $(0.10)$ & $(0.12)$ & $(0.23)$ & $(0.24)$ & $(0.39)$ \\
\hline \multirow[t]{2}{*}{ Founder dyad } & $0.269 * * *$ & $0.308 * * *$ & 0.060 & $0.651 * * *$ & $0.447 * * *$ & -0.109 & $1.369 * * *$ \\
\hline & $(0.06)$ & $(0.06)$ & $(0.08)$ & $(0.10)$ & $(0.17)$ & $(0.21)$ & $(0.32)$ \\
\hline \multirow[t]{2}{*}{ Copenhagen } & 0.031 & -0.058 & $-0.292 * * *$ & $0.255 * * *$ & $1.099 * * *$ & 0.232 & $2.510 * *$ \\
\hline & $(0.05)$ & $(0.05)$ & $(0.07)$ & $(0.08)$ & $(0.17)$ & $(0.19)$ & $(0.39)$ \\
\hline \multirow[t]{2}{*}{ Family firm } & -0.026 & 0.031 & 0.165 & -0.085 & -0.071 & -0.322 & 0.132 \\
\hline & $(0.06)$ & $(0.06)$ & $(0.07)$ & $(0.12)$ & $(0.37)$ & $(0.52)$ & $(0.82)$ \\
\hline \multirow{2}{*}{$\begin{array}{l}\text { Knowledge-intensive } \\
\text { industry }\end{array}$} & $0.423 * * *$ & & & & & & \\
\hline & $(0.06)$ & & & & & & \\
\hline \multirow{2}{*}{$\begin{array}{l}\text { Last-year turnover } \\
\text { (10.000 DKK) }\end{array}$} & $0.003 * * *$ & $0.004 * * *$ & $0.002 * * *$ & $0.004 * * *$ & -0.001 & -0.004 & $0.008 * *$ \\
\hline & $(0.00)$ & $(0.00)$ & $(0.00)$ & $(0.00)$ & $(0.00)$ & $(0.00)$ & $(0.00)$ \\
\hline \multirow[t]{2}{*}{ Constant } & $-4.153 * * *$ & $-4.235^{* * *}$ & $-3.589 * * *$ & $-8.270 * * *$ & $-4.728 * * *$ & $-4.342 * * *$ & $-7.041 * * *$ \\
\hline & $(0.19)$ & $(0.20)$ & $(0.56)$ & $(0.47)$ & $(0.56)$ & $(0.66)$ & $(0.94)$ \\
\hline Year dummies & Yes & Yes & Yes & & Yes & Yes & \\
\hline Startup size dummies & Yes & Yes & Yes & & Yes & Yes & \\
\hline Industry dummies & No & Yes & Yes & & Yes & Yes & \\
\hline Firm age dummies & Yes & Yes & Yes & & Yes & Yes & \\
\hline Pseudo $R^{2}$ & 0.151 & 0.162 & 0.168 & & 0.267 & 0.350 & \\
\hline Log likelihood & -8524.205 & -8419.641 & -9991.035 & & -1138.614 & -1239.418 & \\
\hline$N$ & 36,398 & 36,398 & 36,398 & & 4,323 & 4,456 & \\
\hline
\end{tabular}

Significance levels $* * *<0.01 ; * *<0.05 ; * 0.10$

In models 4 and 5, we look more closely at NVT mobility in knowledge-intensive and hightech industries. In this subsample, some differences stand out. College dyads no longer play a role and are even disadvantageous when it comes to re-entry into entrepreneurship. Dyads that comprise two NVT members with a technical/engineering education have a probability of comobility that is 10.0 p.p. higher compared with the $11.2 \%$ baseline we observe in knowledge-intensive and high-tech industries. This is primarily comobility in another form of employment. Joint shared work experience is also stronger compared with our general sample with a 17.7 p.p. higher probability that comobility occurs. Also, note that this comobility occurs both in entrepreneurship and in other forms of employment. Finally, contrary to the overall sample, the performance of a new venture is only a determinant for re-entering into entrepreneurship. 


\section{Discussion and final remarks}

We know little about what happens to NVTs when new ventures dissolve. It is expected that most NVT members, just like their owner-managers (Jenkins \& McKelvie, 2017), will continue their careers by applying their skills and competencies in other organizational settings. In the context of NVTs, investigating post-dissolution job mobility is valuable as new employers and new attempts to establish a new venture can benefit from the shared experience and team human capital.

We demonstrate that the closure of the new venture does not necessarily mean the end of NVT work relationships, as $18.3 \%$ of the individuals in the sample are shown to have comoved (conditional on being active in the labor market), establishing that NVT comobility is a common phenomenon. Thus, relationships persist after new venture closure, despite the expected diminished quality of social relationships (Sutton \& Callahan, 1987) and the possible stigma around new venture closures (Cardon et al., 2011).

The dyad-level analysis highlights that comobility occurs more frequently among homogeneous groups, indicating that people with similar demographic and human capital characteristics are more inclined to pursue their careers as coworkers. This provides evidence that in line with social categorization theory (Lazarsfeld \& Merton, 1954; McPherson et al., 2001), homophily among team members contribute to the stability of ties. Kim and Aldrich (2002) demonstrated the existence of such stability within new venture teams, but we demonstrate that these ties persist and even outlive the organization in which they are formed. Several reasons might explain such stability, including the existence of common interests (Martin \& Yeung, 2006), lesser degree of personal conflict (Dahlander \& McFarland, 2013), and higher levels of solidarity among team members (Kossinets \& Watts, 2009).

Comobility occurs frequently among individuals whose work is characterized as knowledgeintensive, specifically technical work. This might be explained by the importance of collaboration and interdependencies that emerge in their method of working and the overall complexity of technical work (Janz et al., 1997). In these technical and engineering teams, complementarities may include learning to work with a shared set of tools or technologies. Such mutually dependent work relationships are also more frequent in knowledge-intensive industries in general; consequently, higher rates of comobility are not only found among workers with technical and engineering backgrounds but also among NVT members working in knowledge-intensive startups.

Furthermore, previous social ties play a particularly important role, as prior joint work experience and family ties increase the likelihood of individuals comoving. Therefore, it appears that some individuals follow each other in their careers. Having such strong social ties might be important, as they are believed to improve the performance of both workers and firms (Boselie et al., 2001; Gelderblom \& de Koning, 1996).

The second contribution of this study is the finding that a relatively large share of comovers re-enter into entrepreneurship, large compared with one person attempting to establish a new business. Consequently, many newly established team-based ventures are comprised of individuals who have shared experience of starting new ventures, and they might be referred to as a serial entrepreneurial team. However, the determinants of comobility for established firms and re-entry into entrepreneurship are not the same, particularly when it comes to more highly educated individuals and those who operate in knowledgeintensive industries. A possible explanation of higher levels of comobility might be related to the environmental dynamism in these industries, which is often associated with their higher levels of entrepreneurial orientation (Dai et al., 2016).

The negative emotions associated with business failure, including pain, humiliation, blame, and anger (Cope, 2011; Shepherd, 2003; Singh et al., 2007), may lead to the fear of continuing the entrepreneurial process, and staying together may provide the restart venture with greater access to financial, social, and human resources (Kor \& Mahoney, 2000) needed to re-enter. Furthermore, each team member keeps adding to the variety of views, skills, and knowledge, and this enables the team to complete complex tasks (Ucbasaran et al., 2003). Furthermore, as the re-entry of NVTs occurs frequently, curiosity arises regarding aspects of teamlevel learning from failure within entrepreneurship 
in addition to the individual-level learning currently investigated within the field of entrepreneurship (Nielsen \& Sarasvathy, 2016; Sarasvathy et al., 2013; Shepherd, 2003). Examples of team-level learning could be understanding individual roles in the team, recognizing complementarities in new venture processes as well as the abilities to identify and react upon opportunities as a team.

\subsection{Limitations and future research}

Before concluding, we would like to highlight some limitations of our analysis. Since the study focused on Denmark, how valid our findings are for the institutional context in other countries remains an open question. Furthermore, despite the clear strength of the data when it comes to identifying dissolved new ventures and the ability to track subsequent mobility patterns, there are some limitations regarding the investigation of entrepreneurship. First, there are limitation on firm registrations, and identification of the motivation for startup and closure. In addition, observations are only made once a year; we do not observe startups that kicked off and dissolved within the first year. Also, we only observed individuals with a formal attachment to the organization, and the exact role of everyone in the NVT is not known. Finally, we can only observe that comobility occurs, but we have no information on the underlying motives behind comobility, labor market transition, or the choices made by NVT members.

With these caveats in mind, we have found support for comobility and subsequent team-level reentry into entrepreneurship. Identifying the existence of these mobility patterns opens other avenues for research. To better understand the mechanisms behind this comoving behavior, it would be highly relevant to conduct field work aimed at constructing more grounded theory regarding NVT comobility. This is pivotal because although the findings might infer that both perceived benefits and necessity are at play as NVT members might face mobility constraints, such field work allows researchers to observe different factors that cannot be identified through the dataset used in the present study, including what the underlying motives are for comoving.
Another implication of NVT comobility could be to look at this specific phenomenon from the firm-level perspective. It would be advantageous to understand how entrepreneurs' comobility affects the organization for which they work, following the new venture dissolution. Does the new firm benefit from hiring these entrepreneurs? Besides, since founding a new venture is one of the results of our study, researchers might be interested in exploring how joint movement affects the success of a new venture. Does it alleviate the mortality risk associated with new ventures? So, does it lead to a better understanding of the roles individuals play in the startup? Does it increase legitimacy for the new ventures? Does the new venture perform well, and how can the previous experience of the NVT that closed benefit the performance of the new venture?

Finally, we want to introduce a new perspective to the growing body of literature on serial and habitual entrepreneurship - that is, the serial or habitual entrepreneurial team. The data suggests that this is not an uncommon phenomenon, particularly in high-tech and knowledge-intensive industries. The existence of serial new venture teams would also call for studies that consider team-level perspectives on failure and learning.

Acknowledgements We would like to thank Mirjam van Praag, Diego Zunino, Martin Murmann, Emilie-Pauline Gallié, Mette Præst Knudsen, Michael S. Dahl, and the participants at presentations in seminars at Cornell, the University of Agder, Norwegian School of Economics, and Aalborg University. We are also grateful to four anonymous reviewers for their suggestion and support. All errors are our own.

Funding Open access funding provided by Norwegian School Of Economics.

Open Access This article is licensed under a Creative Commons Attribution 4.0 International License, which permits use, sharing, adaptation, distribution and reproduction in any medium or format, as long as you give appropriate credit to the original author(s) and the source, provide a link to the Creative Commons licence, and indicate if changes were made. The images or other third party material in this article are included in the article's Creative Commons licence, unless indicated otherwise in a credit line to the material. If material is not included in the article's Creative Commons licence and your intended use is not permitted by statutory regulation or exceeds the permitted use, you will need to obtain permission directly from the copyright holder. To view a copy of this licence, visit http://creativecommons.org/licenses/by/4.0/. 


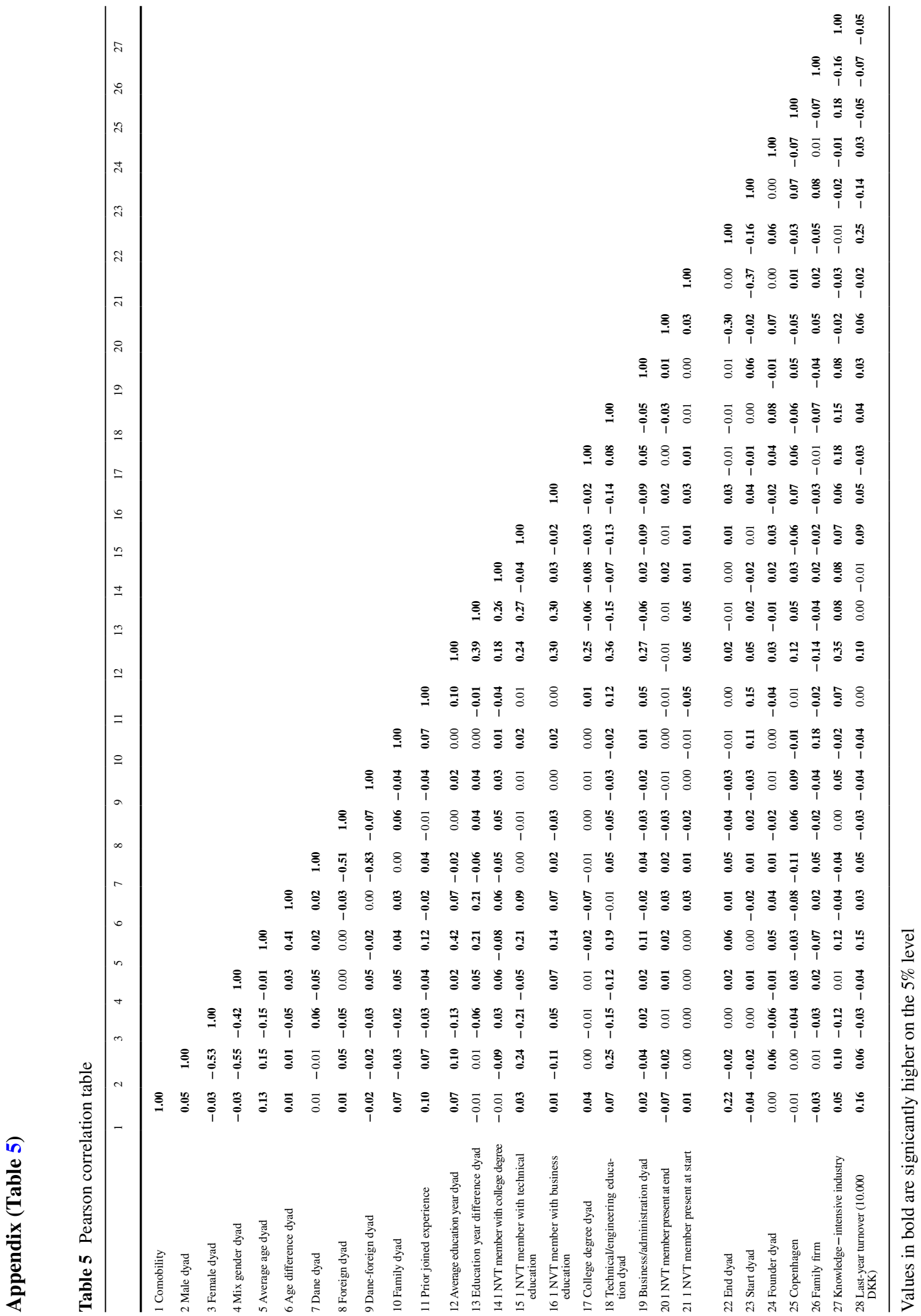




\section{References}

Aggarwal, I., \& Woolley, A. W. (2019). Team creativity, cognition, and cognitive style diversity. Management Science, 65(4), 1586-1599.

Alchian, A. A., \& Demsetz, H. (1972). Production, information costs, and economic organization. The American Economic Review, 62(5), 777-795.

Almeida, P., \& Kogut, B. (1999). Localization of knowledge and the mobility of engineers in regional networks. Management Science, 45(7), 905-917.

Balkundi, P., \& Harrison, D. A. (2006). Ties, leaders, and time in teams: Strong inference about network structure's effects on team viability and performance. Academy of Management Journal, 49(1), 49-68.

Baron, R., \& Ensley, M. (2006). Opportunity recognition as the detection of meaningful patterns: Evidence from comparisons of novice and experienced entrepreneurs. Management Science, 52(9), 1331-1344.

Beckman, C. (2006). The influence of founding team company affiliations on firm behavior. Academy of Management Journal, 49(4), 741-758.

Beckman, C., Burton, M., \& O'Reilly, C. (2007). Early teams: The impact of team demography on VC financing and going public. Journal of Business Venturing, 22(2), 147-173.

Boselie, P., Paauwe, J., \& Jansen, P. (2001). Human resource management and performance: Lessons from the Netherlands. International Journal of Human Resource Management, 12(7), 1107-1125.

Bruderl, J., and Schussler, R. (1990). Organizational mortality: the liabilities of newness and adolescence. Administrative Science Quarterly, 530-547.

Bublitz, E., Nielsen, K., Noseleit, F., \& Timmermans, B. (2018). Entrepreneurship, human capital, and labor demand: A story of signaling and matching. Industrial and Corporate Change, 27(2), 269-287.

Burton, M. D., Dahl, M. S., \& Sorenson, O. (2018). Do startups pay less? ILR Review, 71(5), 1179-1200.

Campbell, B., Coff, R., \& Kryscynski, D. (2012). Rethinking sustained competitive advantage from human capital. Academy of Management Review, 37(3), 376-395.

Campbell, B., Saxton, B., \& Banerjee, P. M. (2014). Resetting the shot clock: The effect of comobility on human capital. Journal of Management, 40(2), 531-556.

Cardon, M., Stevens, C., \& Potter, D. (2011). Misfortunes or mistakes? Cultural sensemaking of entrepreneurial failure. Journal of Business Venturing, 26, 79-92.

Chillemi, O., \& Gui, B. (1997). Team human capital and worker mobility. Journal of Labor Economics, 15(4), 567-585.

Cingano, F., \& Rosolia, A. (2012). People I know; job search and social networks. Journal of Labor Economics, 30(2), 291-332.

Coad, A. (2014). Death is not a success: Reflections on business exit. International Small Business Journal, 32(7), 721-732.

Coad, A., \& Timmermans, B. (2014). Two's company: Composition, structure and performance of entrepreneurial pairs. European Management Review, 11(2), 117-138.
Coad, A., Nielsen, K., \& Timmermans, B. (2017). My first employee: An empirical investigation. Small Business Economics, 48(1), 25-45.

Cope, J. (2011). Entrepreneurial learning from failure: An interpretative phenomenological analysis. Journal of Business Venturing, 26, 604-623.

Dahl, M. S., \& Reichstein, T. (2007). Are you experienced? Prior experience and the survival of new organizations. Industry and Innovation, 14(5), 497-511.

Dahl, M. S., \& Sorenson, O. (2012). Home sweet home: Entrepreneurs' location choices and the performance of their ventures. Management science, 58(6), 1059-1071.

Dahlander, L., \& McFarland, D. A. (2013). Ties that last: Tie formation and persistence in research collaborations over time. Administrative Science Quarterly, 58(1), 69-110.

Dai, Y., Roundy, P. T., Chok, J. I., Ding, F., \& Byun, G. (2016). 'Who knows what?'in new venture teams: Transactive memory systems as a micro-foundation of entrepreneurial orientation. Journal of Management Studies, 53(8), 1320-1347.

Delmar, F., \& Shane, S. (2006). Does experience matter? The effect of founding team experience on the survival and sales of newly founded ventures. Strategic Organization, 4(3), 215-247.

Dokko, G., Wilk, S. L., \& Rothbard, N. P. (2009). Unpacking prior experience: How career history affects job performance. Organization Science, 20(1), 51-68.

Eftekhari, N. (2020). The aftermath of new venture failure. Doctoral Dissertation, Aalborg University

Eisenhardt, K. M., and Schoonhoven, C. B. (1990). Organizational growth: linking founding team, strategy, environment, and growth among US semiconductor ventures, 1978-1988. Administrative science quarterly, 504-529.

Eklund, J., Levratto, N., \& Ramello, G. B. (2020). Entrepreneurship and failure: Two sides of the same coin? Small Business Economics, 54(2), 373-382.

Eurostat (2020) One, three and five year survival rates of enterprises. In: Business Demography Statistics

Gartner, W., Shaver, K., Gatewood, E., \& Katz, J. (1994). Finding the entrepreneur in entrepreneurship. Entrepreneurship Theory and Practice, 18, 5-5.

Gelderblom, A., \& de Koning, J. (1996). Evaluating effects of training within a company: Methods, problems and One8 application. Labour, 10, 319-337.

Gompers, P. A., Huang, K., \& Wang, S. Q. (2017). Homophily in entrepreneurial team formation (No. w23459). National Bureau of Economic Research.

Groysberg, B., Lee, L., \& Nanda, A. (2008). Can they take it with them? The portability of star knowledge workers' performance. Management Science, 54(7), 1213-1230.

Gruenfeld, D., Mannix, E., Williams, K. Y., \& Neale, M. (1996). Group composition and decision making: How member familiarity and information distribution affect process and performance. Organizational Behavior and Human Decision Processes, 67(1), 1-15.

Harper, D. (2008). Towards a theory of entrepreneurial teams. Journal of Business Venturing, 23(6), 613-626.

Head, B. (2003). Redefining business success: Distinguishing between closure and failure. Small Business Economics, 21, 51-61. 
Hoetker, G., \& Agarwal, R. (2007). Death hurts, but it isn't fatal: The post exit diffusion of knowledge created by innovative companies. Academy of Management Journal, 50, 446-467.

Huckman, R., Staats, B., \& Upton, D. (2009). Team familiarity, role experience, and performance: Evidence from Indian software services. Management Science, 55(1), 85-100.

Ingram, P. (2002). Interorganizational learning. In J. A. C. Baum (Ed.), Blackwell companion to organizations (pp. 652-663). Blackwell.

Janz, B., Colquitt, J., \& Noe, R. (1997). Knowledge worker team effectiveness: The role of autonomy, interdependence, team development, and contextual support variables. Personnel Psychology, 50(4), 877-904.

Jenkins, A., \& McKelvie, A. (2017). Is this the end? Investigating firm and individual level outcomes post-failure. Journal of Business Venturing Insights, 8, 138-143.

Kaiser, U., \& Müller, B. (2015). Skill heterogeneity in startups and its development over time. Small Business Economics, 45(4), 787-804.

Kim, P. H., \& Aldrich, H. E. (2002). Teams that work together, stay together: resiliency of entrepreneurial teams. In Babson College, Babson Kauffman Entrepreneurship Research Conference (BKERC) (Vol. 2006).

Kleinbaum, A. M., Stuart, T. E., \& Tushman, M. L. (2013). Discretion within constraint: Homophily and structure in a formal organization. Organization Science, 24(5), 1316-1336.

Klotz, A. C., Hmieleski, K. M., Bradley, B. H., \& Busenitz, L. W. (2014). New venture teams: A review of the literature and roadmap for future research. Journal of Management, 40(1), 226-255.

Kor, Y., \& Mahoney, J. (2000). Penrose's resource-based approach: The process and product of research creativity. Journal of Management Studies, 37(1), 109-139.

Kossinets, G., \& Watts, D. J. (2009). Origins of homophily in an evolving social network. American Journal of Sociology, 115(2), 405-450.

Lazarsfeld, P. F., \& Merton, R. K. (1954). Friendship as a social process: A substantive and methodological analysis. Freedom and Control in Modern Society, 18(1), 18-66.

Lewis, K. (2004). Knowledge and performance in knowledgeworker teams: A longitudinal study of transactive memory systems. Management Science, 50(11), 1519-1533.

Mahieu, J., Melillo, F., Reichstein, T., \& Thompson, P. (2019). Shooting stars? Uncertainty in hiring entrepreneurs. Strategic Entrepreneurship Journal.

Martin, J., \& Yeung, K. (2006). Persistence of close personal ties over a 12-year period. Social Networks, 28(4), 331-362.

Marvel, M. R. (2013). Human capital and search-based discovery: A study of high-tech entrepreneurship. Entrepreneurship Theory and Practice, 37(2), 403-419.

Marx, M., \& Timmermans, B. (2017). Hiring molecules, not atoms: Comobility and wages. Organization Science, 28(6), 1115-1133.

McEvily, B., Perrone, V., \& Zaheer, A. (2003). Trust as an organizing principle. Organization Science, 14(1), 91-103.
McPherson, M., Smith-Lovin, L., \& Cook, J. M. (2001). Birds of a feather: Homophily in social networks. Annual Review of Sociology, 27(1), 415-444.

McPherson, J. M., \& Smith-Lovin, L. (1987). Homophily in voluntary organizations: status distance and the composition of face-to-face groups. American sociological review, 370-379.

Molina, S., \& Kacperczyk, A. J. (2017). Like attracts like? Revisiting demographic homophily in entrepreneurship. In Academy of Management Proceedings (Vol. 2017, No. 1, p. 11544). Briarcliff Manor, NY 10510: Academy of Management.

Moreland, R., \& Myaskovsky, L. (2000). Exploring the performance benefits of group training: Transactive memory or improved communication? Organizational Behavior and Human Decision Processes, 82(1), 117-133.

Nielsen, K., \& Sarasvathy, S. (2016). A market for lemons in serial entrepreneurship? Exploring type I and type II errors in the restart decision. Academy of Management Discoveries, 2(3), 247-271.

Parker, S. C. (2009). Can cognitive biases explain venture team homophily? Strategic Entrepreneurship Journal, 3(1), 67-83.

Pisano, G. (1994). Knowledge, integration, and the locus of learning: An empirical analysis of process development. Strategic Management Journal, 15(S1), 85-100.

Reagans, R., Zuckerman, E., and McEvily, B. (2004). How to make the team: social networks vs. demography as criteria for designing effective teams. Administrative Science Quarterly, 49(1): 101-133.

Roach, M., \& Sauermann, H. (2015). Founder or joiner? The role of preferences and context in shaping different entrepreneurial interests. Management Science, 61(9), 2160-2184.

Rocha, V., \& Van Praag, M. (2020). Mind the gap: The role of gender in entrepreneurial career choice and social influence by founders. Strategic Management Journal, 41(5), 841-866.

Rocha, V., Carneiro, A., \& Varum, C. (2018). Leaving employment to entrepreneurship: The value of co-worker mobility in pushed and pulled-driven start-ups. Journal of Management Studies, 55(1), 60-85.

Roure, J. B., \& Maidique, M. A. (1986). Linking prefunding factors and high-technology venture success: An exploratory study. Journal of Business Venturing, 1(3), 295-306.

Ruef, M., Aldrich, H., and Carter, N. (2003). The structure of founding teams: homophily, strong ties, and isolation among US entrepreneurs. American sociological review, 195-222.

Sarasvathy, S., Menon, A., \& Kuechle, G. (2013). Failing firms and successful entrepreneurs: Serial entrepreneurship as a temporal portfolio. Small Business Economics, 40(2), 417-434.

Shepherd, D. (2003). Learning from business failure: Propositions of grief recovery for the self-employed. Academy of Management Review, 28, 318-328.

Simmons, S. A., Wiklund, J., \& Levie, J. (2014). Stigma and business failure: Implications for entrepreneurs' career choices. Small Business Economics, 42(3), 485-505.

Singh, S., Corner, P., \& Pavlovich, K. (2007). Coping with entrepreneurial failure. Journal of Management and Organization, 13, 331-344. 
Song, J., Almeida, P., \& Wu, G. (2003). Learning-by-hiring: When is mobility more likely to facilitate interfirm knowledge transfer? Management Science, 49(4), 351-365.

Stinchcombe, A. L. (1965). Social structure and organizations, In J. G. March (Ed.), Handbook of Organizations. Chicago: Rand McNally.

Sutton, R., \& Callahan, A. (1987). The stigma of bankruptcy: Spoiled organizational image and its management. Academy of Management Journal, 30, 405-436.

Ucbasaran, D., Lockett, A., Wright, M., \& Westhead, P. (2003). Entrepreneurial founder teams: Factors associated with member entry and exit. Entrepreneurship Theory and Practice, 28, 107-127.

Ucbasaran, D., Westhead, P., \& Wright, M. (2009). The extent and nature of opportunity identification by experienced entrepreneurs. Journal of Business Venturing, 24, 99-115.

Ucbasaran, D., Shepherd, D., Lockett, A., \& Lyon, S. (2013). Life after business failure: The process and consequences of business failure for entrepreneurs. Journal of Management, 39, 163-202.

US Bureau of Labor Statistics (2021). Survival of private sector establishments by opening year. Retrieved from https://www.bls.gov/bdm/us_age_naics_00_table7.txt
Wennberg, K., \& DeTienne, D. (2014). What do we really mean when we talk about 'exit'? A critical review of research on entrepreneurial exit. International Small Business Journal, 32(1), 4-16.

Witt, U. (2000). Changing cognitive frames - changing organizational forms: An entrepreneurial theory of organizational development. Industrial and Corporate Change, 9(4), 733-745.

Zheng, Y. (2012). Unlocking founding team prior shared experience: A transactive memory system perspective. Journal of Business Venturing, 27(5), 577-591.

Zheng, Y., Devaughn, M. L., \& Zellmer-Bruhn, M. (2016). Shared and shared alike? Founders' prior shared experience and performance of newly founded banks. Strategic Management Journal, 37(12), 2503-2520.

Publisher's note Springer Nature remains neutral with regard to jurisdictional claims in published maps and institutional affiliations. 